\title{
The importance of reviewing old investigations in light of new clinical contexts
}

\author{
Angela Pathiraja \\ Department of General Surgery, Lincoln County Hospital, Lincoln, UK
}

Correspondence to Dr Angela Pathiraja, angelapathiraja@nhs.net

\section{DESCRIPTION}

A 70-year-old woman presented with an 8-week history of an enlarging asymmetric and tender abdominal mass and microcytic anaemia but no obvious bleeding, weight loss or change in bowel habit (figure 1). This had been investigated 4 weeks ago, and at that time she was diagnosed with a rectus sheath haematoma (RSH) secondary to previous abdominal wall strain - the main risk factor for RSH, followed by anticoagulation ${ }^{1}{ }^{2}$ - on the basis of ultrasound and subsequent CT findings, and was prescribed iron tablets at this point. However, as the mass persisted, the patient had sought further medical advice.

Although the original diagnosis did fit the presentation, in view of the enlarging mass, worsening anaemia and lack of risk factors for bleeding ${ }^{1}$ (the only medications were atenolol and ferrous fumarate) the patient's scans were re-reviewed by the consultant radiologist and surgeon; the patient was transfused 4 units in the interim. As concerns were raised that this could be an unusual presentation of a malignancy, an urgent colonoscopy was performed that

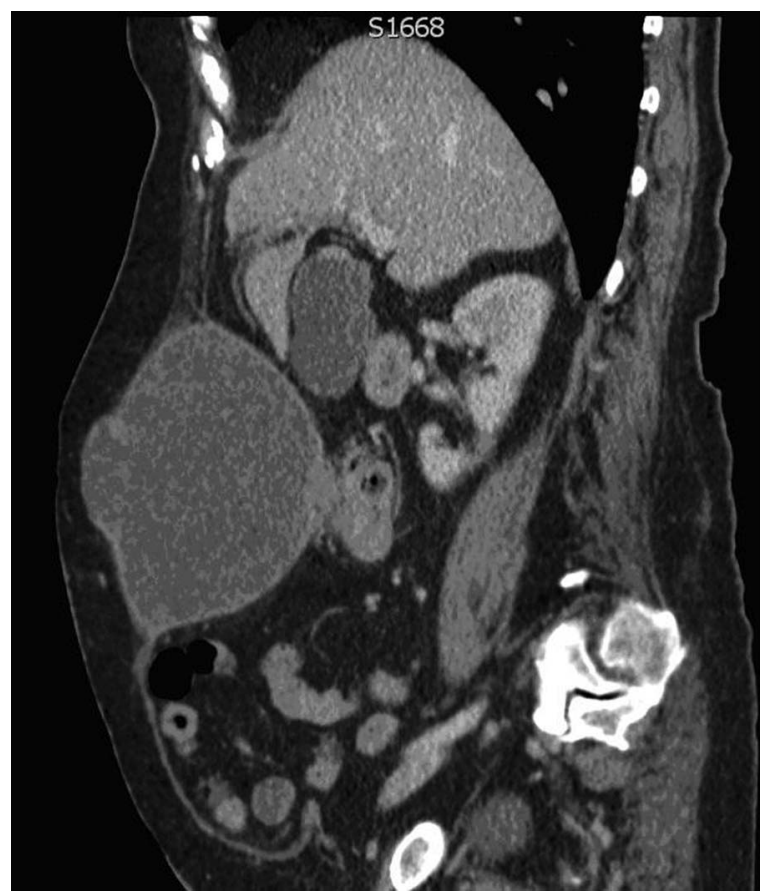

Figure 1 Sagittal view of the abdominal CT scan, showing a large, well-defined, thin-walled homogeneous mass extending into the soft tissue component of the abdominal wall. revealed an obstructing growth in the mid-transverse colon (figure 2). The patient subsequently underwent an open right hemicolectomy and ileotransverse anastomosis for a large colonic carcinoma of the hepatic flexure, which was confirmed at histology to be a moderately differentiated T4aN0MX Dukes B adenocarcinoma invading the anterior abdominal, with rupture and fistula tract formation, thereby mimicking an RSH.

Colonic cancers can occasionally invade the abdominal wall, but have rarely been documented to bleed and fistulate. $^{3}$ This case highlights that the review of previous investigations in the context of the whole clinical picture is imperative for the swift diagnosis and management of this unusual presentation of bowel cancer.

Learning points

- Review of previous investigations is crucial when assessing patients, especially those who present with recurrent or non-resolving issues.

- Obtaining a second opinion, especially with regard to unusual presentations, can often be crucial in aiding diagnosis and subsequent management of the presentation.

- Just as rectus sheath haematomas can mimic more sinister pathologies, these pathologies can mimic the presentation of a rectus sheath haematoma.

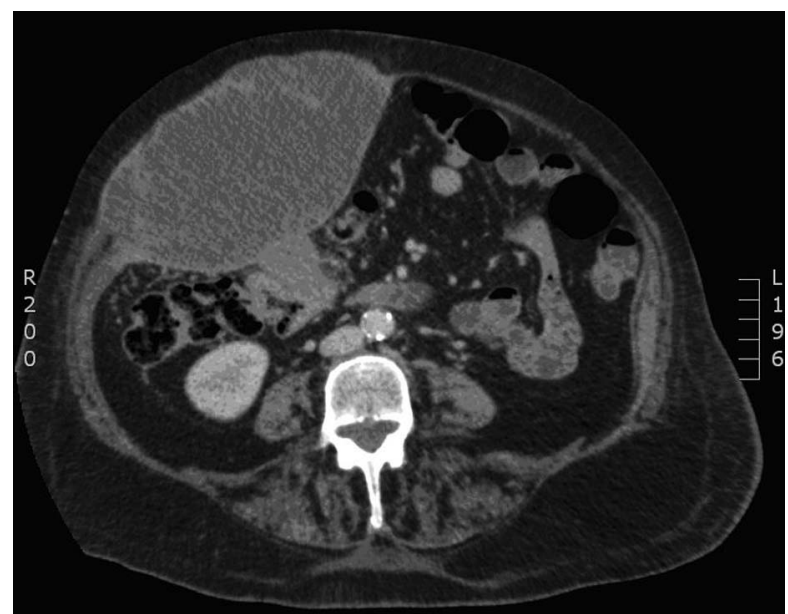

Figure 2 Axial view of the abdominal CT, showing the mass lying adjacent to the proximal transverse colon. 


\section{BMJ Case Reports}

\section{Competing interests None.}

Patient consent Obtained.

\section{REFERENCES}

1. Fitzgerald JE, Fitzgerald LA, Anderson FE, et al. The changing nature of rectus sheath haematoma: case series and literature review. Int J Surg 2009;7:150-4.
2. Sharma H, Shekhawat NS, Bhandari S, et al. Rectus sheath haematoma: a rare presentation of non-contact strenuous exercises. Br J Sports Med 2007:41:688-90.

3. Bogdanic B, Augustin G, Kekez T, et al. Perforated ascending colon cancer presenting as colocutaneous fistula with abscess to the anterior abdominal wall at the site of a cholecystectomy scar treated with biologic mesh. Collegium Antropologicum 2012;36:335-8.

Copyright 2012 BMJ Publishing Group. All rights reserved. For permission to reuse any of this content visit http://group.bmj.com/group/rights-licensing/permissions.

BMJ Case Report Fellows may re-use this article for personal use and teaching without any further permission.

Please cite this article as follows (you will need to access the article online to obtain the date of publication).

Pathiraja A. The importance of reviewing old investigations in light

of new clinical contexts. BMJ Case Reports 2012;10.1136/bcr.11.2011.5207, Published XXX

Become a Fellow of BMJ Case Reports today and you can:

- Submit as many cases as you like

- Enjoy fast sympathetic peer review and rapid publication of accepted articles

- Access all the published articles

- Re-use any of the published material for personal use and teaching without further permission

For information on Institutional Fellowships contact consortiasales@bmjgroup.com

Visit casereports.bmj.com for more articles like this and to become a Fellow 